\title{
INTERNATIONALIZATION OF HIGHER EDUCATION
} IN TERMS OF PUBLIC ADMINISTRATION

\section{IНТЕРНАЦІОНАЛІЗАЦІЯ ВИЩОЇ ОСВІТИ: УПРАВЛІНСЬКИЙ АСПЕКТ}

UDC 378.014:339.94]:351

DOI https://doi.org/10.32843/2663-52402019-11-11

\section{Kostiuk T.O.}

$\mathrm{PhD}$ in Political Science, Associate

Professor,

Senior Research Fellow,

Scientific Research Laboratory

of Internationalization of Higher Education

Borys Grinchenko Kyiv University
Nowadays many societies and countries are becoming more and more focused on themselves as the backlash against globalization. On the contrary educational field strives to unification and generalization. The main vectors on which the modern international component of higher education develops is, firstly, the unification of scientific and pedagogical efforts and resources, and secondly, academic mobility and programs of double diplomas. The greatest success is observed in educational field demonstrating harmonic combination of outstanding national traditions and scientific schools' approaches with the world trend toward internationalization. State policy of Ukraine, including educational field, is constantly aimed at achieving world standards for the sake of joining democratic developed countries and shared future in a fractured world. Thus, it has to correspond to the world trends. Key words: internationalization of higher education, academic mobility, globalization, national identity, market oriented higher education, Ukraine.

Сьогодні багато суспільств і держав стають дедалі більше орієнтованими на національні проблеми, що є наслідком негативного впливу глобалізачії. Освітня ж сфрера прагне уніфікації та узагальнення стандартів та підходів. Основними векторами розвитку сучасної міжнародної складової частини вищої освіти є, по-перше, уніфрікація науково-педагогічних зусиль $і$ ресурсів, по-друге, академічна мобільність і програми подвійних дипломів. Найбільший успіх спостерігається в освітній сфрері через гармонійне поєднання провідних національних традичій та підходів наукових шкіл зі світовою тенденцією до інтернаціоналізації. Державна політика України, включаючи освітню среру, постійно спрямована на досягнення світових стандартів задля приєднання до демократичних розвинених країн і спільного майбутнього в мінливому світі, тому повинна відповідати світовим трендам.

Ключові слова: інтернаціоналізація вищоі освіти, академічна мобільність, глобалізація, національна ідентичність, ринково орієнтована вища освіта, Україна.

Сегодня многие общества и государства становятся все больше ориентированными на национальные проблемы вследствие негативного влияния глобализации. Образовательная же ссрера стремится $к$ унифрикации и обобщению стандартов и подходов. Основными векторами развития современной международной составляющей высшего образования является, во-первых, унифрикация научно-педагогических усилий и ресурсов, во-вторых, академическая мобильность и программы двойных дипломов. Наибольший успех наблюдается в образовательной сфрере благодаря гармоничному сочетанию ведущих национальных традиций и подходов научных школ с мировой тенденцией к интернационализации. Государственная политика Украины, включая образовательную сферу, направлена на достижение мировых стандартов для присоединения к демократическим развитым странам и общего будущего в меняющемся мире, поэтому должна отвечать мировым трендам.

Ключевые слова: интернационализация высшего образования, академическая мобильность, глобализация, национальная идентичность, рыночно ориентированное высшее образование, Украина.
The problem setting in general. The internationalization of higher education (IHE) is now a fashionable buzzword and at the national, sectoral and institutional levels makes the functions and mechanism of providing educational services acquire an international character. At present, all over the world the internationalization of education is becoming an object and subject of a purposeful State policy, aimed at solving educational, institutional, political, social and economic problems. As well we might conceive national peculiarities and in what ways they remain a differentiating component of higher education institutions and, particularly, how it may help distinguish approaches to internationalization.

To reveal and to discuss multiple definitions, terms and approaches to internationalization present in literature and higher education practice would go far beyond the scope of this article. Accordingly, the controversy and effect of internationalization, seen through the lens of regional perception peculiarities, threats and opportunities, are of central interest.

The main categories for the comprehensive analysis of IHE trends are the national and supranational structures and the principles of interaction at all levels. Hence, there is a need for a thorough study of ideas, principles, forecasting of priorities, internationalization of education policy in world, regional and national dimensions. It is also worth to determine the specificity of the IHE in different regions and states and to track the corresponding activity of educational institutions, students and teachers. Equally important is to monitor the application areas of international cooperation in higher education. All these aspects have been examined and set forth in this article.

Analysis of the related research and publications. Actually, the IHE concept besides two generally admitted aspects of internal and 
external internationalization must include the border-omission elements and features. It undoubtedly has to promote the multiculturalism and to contribute to the elimination of borders in minds, approaches to studying and scientific research as well as the gap in goal-setting, decision-making way of thinking.

A simple, generic definition of internationalization is suggested by Maringe and Foskett, drawing on the work of Knight, de Wit and Teichler, that describes internationalization in the context of HE as "the integration of an international or intercultural dimension into the tripartite mission of teaching, research and service functions" [2-4;6]. In an often-cited definition of internationalization of higher education, Knight [2] states: "Internationalization is the process of integrating an international or intercultural dimension into the teaching, research, and service functions of an institution of higher learning". In a similar process-oriented definition Altbach, Reisberg and Rumbley note: "[internationalization refers to] specific policies and programs undertaken by governments, academic systems and institutions, and even individual departments" [1]. It is noteworthy that both authors pivot the definition on infusion of an approach to reach out and interrelate with other nations. Au contraire, the proliferation of globalization is described as "tentacular spread". Middlehurst \& Woodfield have observed that internationalization has impacted higher education primarily in two ways: first, it has made the higher education sector more competitive, and secondly, it has driven institutions to devise policy prescriptions at the organizational level [5]. The former implies that higher education the world over is viewed as a global marketplace for international students, academics and research funds. The understanding that internationalization of higher education adds competitive advantage drives institutions to incorporate the international element. This view perceives institutions to be partakers in the global marketplace of higher education and to prepare the future workforce to meet the demands of global career.

Formulating the goals of the article. The article first examines internationalization, proceeding from its provenance and generally accepted growing role in higher education. It then questions how it correlates, influences or depends on the globalization, multiculturalism, political vectors and national identity and academic traditions. Above all the article argues that the internationalization only strives to enrich and pattern scholar and cultural spheres, is not linked to the contestations of power, extending the perennial role of education in keeping overall presence in countries' policy. And finally, the article warns that developing countries' mentality leads to a simplified perception of the internationalization as welfare growing strategy that intimately tends to consumerism.

Presentation of the main research material. The integration of higher education major factors includes economic, political, cultural, and pedagogical. Economic factors are related both to direct financial benefits (income from tuition fees for foreigners, language courses, internships, etc.), and indirect economic benefits, primarily an advanced training of high school graduates as a condition for lifelong education and economic progress. Political factors are defined by geopolitical interests, security issues, ideological influence, etc. Cultural factors emerged due to the importance of intercultural dialogue. Pedagogical factors influence the function and content of IHE. All these factors are closely intertwined and evolve.

By the end of the 1990s, overall internationalisation and especially in the field of higher education was largely initiated and guided by political factors, above all by the desire to ensure the coexistence of different social systems, to strengthen cultural understanding and the political influence. Realities have changed, but the political processes in some countries and regions continue to shape and to adapt the requirements for educational processes. The world leading countries presence in the state-building processes in transitive societies through internalisation of the educational field determines their influence on the mass consciousness formation, the development of sciences, democratisation as well as the ideological dominance. For instance, the conferences devoted to nowadays most pressing problems and, especially, their scientific exploration, are more and more frequently conducted on the basis of the leading universities in Asian and African countries. Except of creating an ideal platform for discussion, reflection and exchange, it made possible world progressive thoughts set up the prerequisites for further regional research trends and vectors.

The world community advocates that science should be out of politics. However, often in autocratic or semi-democratic regimes, science gets censored or sanctioned. The censorship in science appears particularly as regards the topic of scientific research, publicity or secrecy of the thesis defense, the publication of scientific and practical experiments results. As well if they sanction the country, they sanction small business, scientific field and sports, as repeatedly concerning Cuba or Russia.

IHE promotes unification of research requirements. In the post-Soviet space, the system 
of doctoral studies has been so stiff, corrupt and guided from above that in some fields of sciences became a valuable option for those elected who could afford postgraduate education. Thanks to the spread of higher education world quality standards and the requirements to the scientific works, the research and investigation projects have become truly scholastic, what is confirmed by the citation index, with significant scientific novelty and relevance, proven through the promulgation of scientific discourse on the subject. An application for the publication of the scientific research results in an international edition provides a kind of arbitration, which acts impartially within the accepted standards and requirements framework. To receive approval and to be admitted to publication in the editions included in bibliographic abstract databases is at the same time a high estimation at the supranational level of the scientist's contribution to the development of domestic science.

Besides, expanding the horizons for young scholars has made it compulsory to speak a foreign language, at least English. This, in turn, causes operational changes in public policy. In the light of the IHE process in developing countries and countries-aspirants to join the world scientific community on parity rights, the legislation in the sphere of education, science and language policy is being adapted. In Ukraine, these requirements of time are reflected primarily in the Law of Ukraine "On Education", the Law of Ukraine "On Higher Education" and the Law of Ukraine "On the Principles of State Language Policy".

Among other things, the IHE path trotting may imply the creation of a "market-oriented high school", the rejection of universal academic training, the formation of knowledge and skills and capacity building as the instruments of action on the global education market. Likewise, the disappearance of political and ideological imbalances in the world, the proclamation of the universal values of socio-humanitarian development, environmental issues, the rapid growth of the Asia-Pacific region, China and Japan's increasing influence on the world economy, Korea's potential, the threshold states' achievements in nuclear weapon exploration indicate new priorities in education.

Additionally, unified requirements and approaches to the organization of the learning process and the research enrich the traditions of national universities in the world. Thus, for instance, joint programs are integrated, differentiated by degree (bachelor, master, doctoral, consecutive) and type of diploma (two (or more) diplomas, double diploma, joint certification). The IHE process besides students' and academic mobility includes the programs and cur- ricula reforming and cooperation in the research field through different networks and associations. Open and distance learning, regional and foreign institutions cooperation to create strategic educational alliances, international division of labor and other activities are also among advantages.

Among the advantages of IHE are the pooling of resources, especially when they are so inaccessible, and avoiding of duplication and redundant copying of research topics along with the identification of educational projects. The given process also provides the possibility to push the limits of scientific search, preserve national identity while expanding the cultural horizons of trainees and trainers, influence the development of the country of origin and contribute to global economic and political stability.

Taking into account IHE characteristics and the positioning of the countries in educational services it is possible to identify educational services as import-oriented, import-export oriented and export-oriented types of HEls orientation. For this reason, IHE demonstrates its effectiveness first due to the expansion of curricula and training of their students in foreign partner universities. The expansion of the universities' regional network for the effective resources use and the education and research quality improvement through the participation of students and teachers in knowledge sharing process go the next.

As practice shows, there have recently emerged new forms of internationalisation, consisting in the institutions and programs transfer across the border. These forms of international supply of educational services, called the transnational education, are considered to be appropriate educational activities, in which students are not in the country where the HEl that issues diplomas is located. Indeed, the most characteristic forms of mobility of institutions are: the opening of foreign campuses by universities and/or commercial suppliers or the creation of a new higher education institution in which foreign capital takes part either alone or in partnership with a national university. Moreover, the mobility of educational programs includes distance education courses offered by a university located abroad; joint courses or programs offered by an internal university and its foreign partner institution; as well as franchising courses and programs. Hence, the procedure of IHE demonstrates the sustainable development and diversification.

Au contraire, internationalisation at domicile is a concept which is a way to ensure that the majority of students who do not have the opportunity to study abroad, nevertheless, can take advantage of the effects of international influence. It means the introduction of educational programs/disci- 
plines in foreign languages; integration of foreign visiting professors in the educational process; introduction of joint programs without obligatory or with short-term student mobility.

Conclusions. Education is only one link in the national development strategy, which determines the country's ranking in different fields, its priority and authority in the world. Qualitative education with an emphasis on patriotic national education is at the basis of the general policy of the state, its socio-humanitarian component is aimed at preserving the national identity with the parallel intensification of the process of sectoral implementation of innovations and world trends.

IHE is a process that has become a manifestation of globalization in science and education. This tendency is to unify standards, specialties, educational qualification levels, curricula and programs, requirements, evaluation systems; it is a program of student and academic exchanges, double diplomas; it is an academic dialogue, the dissemination of experience. But among others there is the issue of the economic development of educational institutions, based on the opening of language courses, summer camps, preparatory faculties. It is also a matter of political influence, and even expansion. For example, sponsoring educational institutions or educational/ research projects, creating enabling environments, programs, brain drain grants, language policy, co-financing research, creates a donor country with all the conditions for political presence in the domestic policy of the recipient country. This should be remembered by the countries of the former USSR, which in their search for a development vector often hesitate between Asian, or European, areas of cooperation and funding sources.

Ukraine is always a progressive state, which in many spheres leads the countries with advanced technologies. Education is not an exception.
Ukrainian scholars and educators are known all over the world, their experience and development are highly appreciated; innovations have been recognized and sponsored by numerous projects and grants, either European or American. Lack of State financing and public funding leads to the fact that the behavior of Ukrainian higher educational institutions is adaptive, they turn into grant-eaters, lose the renown of the advanced institutions of higher education in their field. In order to stop such destructive tendencies, to bring higher education in Ukraine to a qualitatively new level, to retain the status of leaders in their fields by Ukrainian higher education institutions, it is necessary to carry out certain reforms.

\section{REFERENCES:}

1. Altbach P., Reisberg L. \& Rumbley L. (2009). Trends in Global Higher Education: Tracking an Academic Revolution. A Report Prepared for the UNESCO 2009 World Conference on Higher Education. Paris, France : UNESCO.

2. Knight J. Internationalization: Elements and checkpoints. Canadian Bureau for International Education. Ottawa, Canada : CBIE. 1994.

3. Knight J. Internationalization remodeled: Definition, approaches, and rationales. Journal of Studies in International Education. 8, 5-31. 2004. URL: http://dx.doi.org/10.1177/1028315303260832.

4. Maringe F. \& Foskett N. Introduction: Globalization and universities. In F. Maringe \& N. Foskett. Globalization and internationalization in higher education: theoretical, strategic and management perspectives (pp. 1-16). London / New York : Continuum International Publishing Group, 2010.

5. Middlehurst R. \& Woodfield, S. Responding to the internationalisation agenda: Implications for institutional strategy.2007.URL:http://www.heacademy.ac.uk/assets/ documents/research/responding_to_the internationalisation_agenda_full_report.pdf.

6. Teichler U. Comparative Higher Education. Potentials and Limits. Higher Education. 1996. 32 (4): 431-465. 